\title{
Polychaetes associated with decaying wood in Térraba mangrove, South Pacific, Costa Rica
}

\author{
Jeffrey A. Sibaja-Cordero ${ }^{1,2} \&$ Silvia Echeverría-Sáenz ${ }^{1,3}$ \\ 1. Museo de Zoología, Escuela de Biología, Universidad de Costa Rica, San Pedro, San José 11501-2060, Costa Rica. \\ 2. Centro de Investigación en Ciencias del Mar y Limnología (CIMAR), Ciudad de la Investigación, Universidad de \\ Costa Rica, Costa Rica; jeffro@costarricense.cr \\ 3. Instituto Regional de Estudios en Sustancias Tóxicas (IRET), Universidad Nacional, Heredia, Costa Rica; \\ silvia.echeverria.saenz@una.cr
}

Received 11-VIII-2014. C Corrected 20-XI-2014. Accepted 22-XII-2014.

\begin{abstract}
The present study shows spatial patterns in the faunal assemblage of decaying wood and sediments, with emphasis on the polychaetes. The survey was executed across a salinity gradient in a tropical mangrove estuary of Costa Rica. To capture the organisms we analyzed decomposing logs found in the Térraba mangrove and sediment samples were taken with a corer in the sand bottom. Seven different phyla were found in the sediment samples. Of the 192 individuals found in the sediment samples, 18 were polychaetes belonging to nine families and 11 species. Analyses of decaying wood resulted in 2564 individuals distributed in five phyla. Polychaetes accounted for 429 individuals belonging to eight families and 16 species. Although, polychaetes were more abundant in decaying wood, and their diversity was lower. The abundance of polychaetes in decaying wood was negatively correlated with the number of individuals of Mollusca, Hexapoda and Crustacea. A change in the composition of polychaetes in decaying wood was found along the salinity gradient of this estuarine zone. Dissimilarities in the composition of benthic fauna in decaying wood and sediments in the Térraba mangrove showed that biodiversity was increased by the microhabitats inside the mangrove forest. Finally, several genera or species of polychaetes are new records for Costa Rica and the Central American Pacific Coast. Rev. Biol. Trop. 63 (Suppl. 1): 61-74. Epub 2015 April 01.
\end{abstract}

Key words: Térraba mangrove, Namaneridinae, biodiversity, estuarine ecology, polychaetes.

Mangroves are transition ecosystems between marine and terrestrial habitats. They are representative of tropical and subtropical regions where they reach their greatest development (Lacerda et al., 1993; Jiménez, 1994; Mainardi, 1996; Oshiro, Silva, \& Silva, 1998). As mangroves are a combination of marine, terrestrial and freshwater habitats a great variety of fauna can be found (Jiménez, 1994), and their existence depends on the tides, time of the year, life cycle, (Wehrtmann \& Dittel, 1990; Dittel, Epifanio, \& Lizano, 1991; Lacerda et al., 1993; 2001; Macintosh, 1988).

In spite of this known high biodiversity, there are few studies that include detailed quantification and identification of organisms
(Skov, Vannini, Shunula, Hertnoll, \& Cannicci, 2002). Jiménez (1994) indicated that taxonomic and comparative studies are lacking, especially in the Central American region. Polychaetes are one of the main groups in soft bottoms, and some inhabit mangrove roots and decaying wood (Alongi, 1990; Molina-Lara \& Vargas, 1995; Glasby, 1999; Dean, 2004). The main studies concerning intertidal fauna in sediments or mangroves have been developed in the Gulf of Nicoya, Costa Rica (Vargas, 1987; Perry, 1988).

The Térraba-Sierpe mangrove is classified as a wetland of international importance (RAMSAR site), and it is the biggest mangrove forest in Costa Rica (Cordero, 2000), 
representing almost $40 \%$ of the total mangrove forests of the country (Lahmann, 1999). Chicas (1995), Vega (1994), and Echeverría-Sáenz, Vargas and Wehrtmann (2003) have worked in this mangrove with commercial ichtyofauna, populations of Anadara (Bivalvia), and taxonomic diversity of decapods, respectively. However, the region of Térraba-Sierpe lacks studies of other marine invertebrates.

In this paper, we present data on the faunal assemblage, with emphasis on polychaetes, present in decaying wood. Additionally, the relationship of this fauna of decaying wood with the salinity gradient in a tropical mangrove of Costa Rica is analyzed

\section{MATERIALS AND METHODS}

Study area: Térraba-Sierpe is located in Puntarenas province on the South Pacific coast of Costa Rica (Cordero, 2000). This mangrove has an area of 16700 ha (Lahmann, 1999). The most common tree species at Térraba are $R h i$ zophora mangle, Rhizophora racemosa, Pelliciera rhizoporae, and Mora oleifera (Mainardi, 1996). The average annual precipitation and temperature are $3638 \mathrm{~mm}$ and $26.5^{\circ} \mathrm{C}$, respectively (Cordero, 2000). Because of its high precipitation and the great amount of freshwater throughout the year, Térraba, together with Sierpe and Golfito, are the structurally most developed mangroves of the country with canopies that reach $40 \mathrm{~m}$ in height (Jiménez \& Soto, 1985; Polanía, 1993; Silva, 2009).

Methodology: Ten field trips were made in order to collect fauna samples between July 2002 and July 2003, covering both dry and rainy seasons. The sampling date by station is shown in Fig. 1. At each sampling site (Fig. 1),

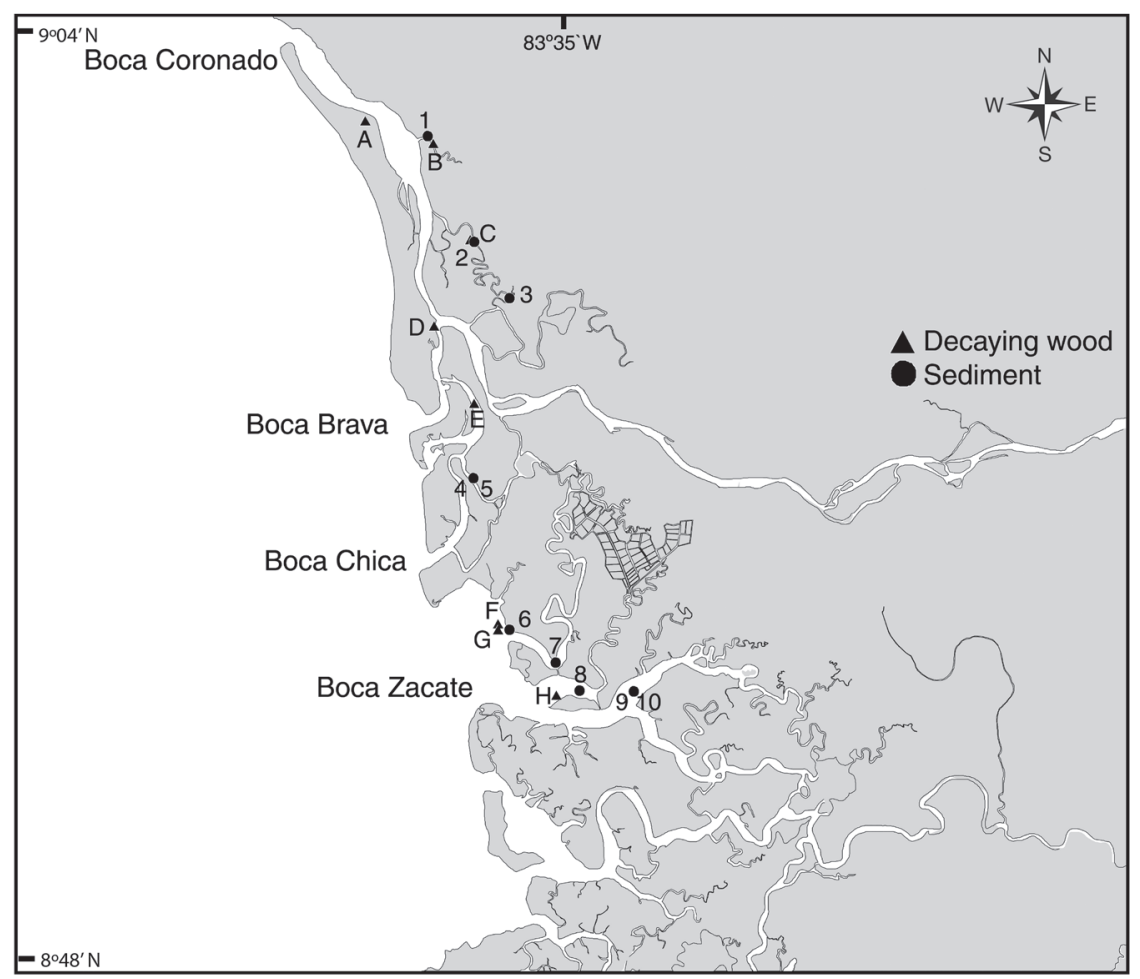

Fig. 1. Sampling stations for sediment (1-10) and decaying wood (A-H), in the Térraba mangrove, South Pacific of Costa Rica. July 2002 and July 2003. Sediment sampling date: 1=August 2002; 2, 3, 6 and 8=November 2002; 4=June 2002; 5=September 2002; 7=December 2002; 9 and 10=February 2003. Decaying wood sampling date: A=February 2003; B, $\mathrm{D}=$ November 2002; C=January 2003; E, F=October 2002; G=September 2002; H=August 2002. 
geographic coordinates were taken with the help of a Garmin eMap GPS. Time, collecting technique, salinity (PSU) using a WTW LF 340 refractometer, and the substrate type (sediments or decaying wood) were also annotated.

The first goal was the collecting of decapod species (Echeverría-Sáenz et al., 2003), however, in the present study we identified other faunal groups found in these samples. To capture the organisms that lived in the decaying wood we collected one fairly decomposed log (approximately $60 \mathrm{~cm}$ long x $12-15 \mathrm{~cm}$ diameter) from each field trip (Fig. 1). This log was packed in a plastic bag directly in the field to prevent animals from escaping. Once in the lab, the log was broken down into smaller pieces which were then put in a bowl with a formalin solution $(5 \%)$. To remove the associated fauna the larger pieces were washed and sieved through a $1 \mathrm{~mm}$ mesh, and all the remaining mixture of small pieces of wood, and animals, were separated using a dissecting microscope.

Sediment samples (Fig. 1) were taken with a core that consists of a pump made with PVC $(5.5 \mathrm{~cm}$ diameter, $15 \mathrm{~cm}$ in the sediment). This pump was placed on top of the exit holes of organisms and the mud was sucked up, and the resulting mud core was sieved through a $1 \mathrm{~mm}$ mesh. We also used a shovel to remove mud $(5.5 \mathrm{~cm}$ diameter, $15 \mathrm{~cm}$ in the sediment) when the holes were not evident was sieved through the $1 \mathrm{~mm}$ mesh. All organisms were fixed in a 5\% formalin solution, and later stored in $70 \%$ alcohol.

All samples were processed, and organisms were identified after each field trip at the Museo de Zoología and CIMAR of the Universidad de Costa Rica. Polychaetes were identified with the keys of Fauchald and Reimer (1975), Salazar-Vallejo, León-Gonzalez and Salaices-Polanco (1988), Glasby (1999), Dean (2001a) and de León-González et al. (2009), and original descriptions cited in the results. Voucher specimens have been deposited at the Museo de Zoología, Universidad de Costa Rica (MZ-UCR).

The free software PAST was used in the data analysis (Hammer, Harper, \& Ryan,
2001), The Shannon-Wiener diversity index $\left(\mathrm{H}^{\wedge}\right)$, equitability of Pielou $(\mathrm{J})$, and T statistictest for Shannon-Wiener were calculated for the polychaetes of sediment and decaying wood samples. The 95\% confidence limits of Shannon-Weiner values were calculated using the Jackknife technique (Krebs, 1999). The similarity of species identity was measured with Sorensen presence/absence index (Krebs, 1999).

The Cramer's V was used to measure the relationship of polychaetes with the other taxonomic groups found only in the decaying wood samples. The results were plotted with a 2-axis Correspondence Analysis of the taxa/ station abundance data. The direction and rate of increase in number of individuals of each taxonomical group were represented by vectors (Quinn \& Keougth, 2003). Finally, a Principal Component Analysis of a correlation matrix (Quinn \& Keougth, 2003) was carried out with the abundance data of taxa found in decaying wood in relation to the salinity level (PSU) measured in the field during the sampling event. The goal of this technique was to show the similarity in the distribution of taxa along the salinity gradient.

\section{RESULTS}

Sediment samples yielded 192 individuals belonging to seven phyla; Annelida, Arthropoda, Chordata, Echinodermata, Mollusca, Nemertea and Sipuncula. Polychaetes were found in only four of the 10 sediment samples and accounted for 18 individuals belonging to nine families and 11 species. On the other hand, 2564 individuals were found in the eight decaying wood samples belonging to five phyla; Annelida, Arthropoda, Cnidaria, Mollusca and Nemertea. Polychaetes occurred in all wood samples with 429 individuals belonging to 16 species in eight families. Additionally, there were two Oligochaeta specimens in the sediment samples and 183 individuals in the decaying wood samples. The annelid worms represented 10.4 and $23.9 \%$ of the total abundance of organisms in sediment and decaying 
wood samples, respectively (Fig. 2). Hexapoda (mainly Diptera larvae) and Pholadidae (Bivalvia) were present only in the wood samples. Echinodermata and Sipuncula were absent in wood samples (Fig. 2).

The diversity of polychaetes and their equitability were higher $(\mathrm{t}=2.40, \mathrm{p}=0.025)$ in the sediment $\left(\mathrm{H}^{\wedge}=2.32+/-0.57, \mathrm{~J}=0.97\right)$ than in the decaying wood $\left(\mathrm{H}^{\wedge}=1.67+/-0.29, \mathrm{~J}=0.60\right)$. Taxa richness was similar between sediment (11) and wood samples (16) $\left(\chi^{2}=0.93, p=0.33\right)$ but these taxa showed low similarity to each other (Sorensen=0.44) (Table 1). The sediment tube builders Diopatra ornata Moore, 1911, Owenia collaris Hartman, 1955, and the gallery worm Goniadidae indet. were only found
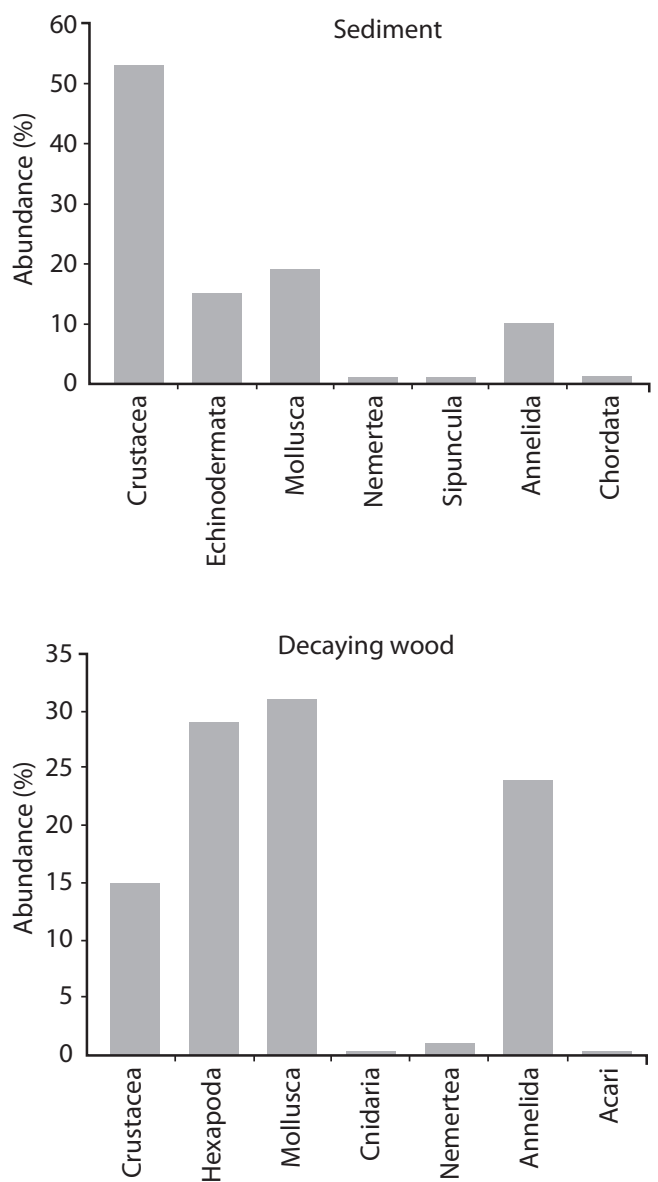

Fig. 2. Percent of total abundance of the taxonomical groups by substrate. Térraba mangrove, Costa Rica. 2002/2003. in the sediment samples. Decaying wood was dominated mainly by capitellids and oligochaetes. Although, six of the seven species of Nereididae were present in the decaying wood, Alitta succinea (Leuckart, 1847) and Namaneries sp. were the most abundant. The Namaneridinae family only occurred in decaying wood (Table 1).

The decaying wood of Boca Zacate (Fig. 1) presented low numbers of invertebrates (Fig. 3B) but in stations $\mathrm{F}$ and $\mathrm{H}$ at least $49 \%$ of them were polychaetes, representing the stations with the greatest percentage contributions of these worms (Fig. 3A). Stations A and B of Boca Coronado (Fig. 1) had nearly 190 individuals and polychaetes were also dominant in the most external station A (Fig. 3A) but only represented $18 \%$ of the abundance in the most internal station B (Fig. 3B). The stations $\mathrm{A}, \mathrm{B}$, and $\mathrm{E}$ had high numbers of capitellids (31-76 ind.) and oligochaetes (2785 ind.), but low numbers of other polychaete families. Capitellids and oligochaetes were scarce in the rest of the stations $(<10$ ind.). Additionally, the most internal stations in the mangrove (E, D, and $\mathrm{C}$ ) had the highest total abundances of invertebrates (Fig. 1,3B). The polychaetes were most abundant in station $\mathrm{E}$ (117 ind.), but represent only $33 \%$ of the fauna. In station $\mathrm{D}$, a high number of insect larvae were found, and the most abundant polychaete was Namaneries sp. with 76 individuals. The abundance of polychaetes in decaying wood was negatively associated with the number of individuals of Mollusca ( $\mathrm{V}=0.78, \mathrm{p}<0.001)$, Hexapoda $(\mathrm{V}=0.75, \mathrm{p}<0.001)$, and Crustacea $(\mathrm{V}=0.64, \mathrm{p}<0.001)$. Station $\mathrm{C}$, which had a high abundance of these groups, also had low total polychaetes abundance (Fig. 3A, B).

Some of the association patterns observed between species in the decaying wood could be explained by the salinity gradient. Hexapoda, Namanereis worms, capitellids, and Acari showed their maximum abundance at low salinity stations (0-0.2 PSU) (Fig. 4). Crustacea, Mollusca, and Oligochaeta dominated in salinities between 4 and 10 PSU. Six species of polychaetes occurred at 13 PSU. This section 
TABLE 1

Polychaetes and total number of individuals in the decaying wood and sediment samples.

Térraba mangrove, Costa Rica. 2002/2003

\begin{tabular}{|c|c|c|c|c|}
\hline Family & Species & Wood & Sediment & $\begin{array}{c}\text { Museum } \\
\text { catalogue number }\end{array}$ \\
\hline Amphinomidae & Linopherus oculata (Treadwell, 1941) * & 5 & & MZ-UCR 139-03 \\
\hline Capitellidae & Capitellidae indet. & 181 & 1 & \\
\hline Goniadidae & Goniadidae indet. & & 2 & \\
\hline Lumbrineridae & Scoletoma uncinigera (Hartmann-Schröder, 1959)* & 1 & 1 & MZ-UCR 135-01 \\
\hline Nepthyidae & Nephtys singularis Hartman, 1950 & 1 & 1 & MZ-UCR 137-02 \\
\hline \multirow[t]{8}{*}{ Nereididae } & Ceratonereis singularis Treadwell, 1929 & 1 & & MZ-UCR 279-01 \\
\hline & Namalycastis kartaboensis (Treadwell, 1926)** & 1 & & MZ-UCR 134-01 \\
\hline & Namanereis sp. ** & 92 & & MZ-UCR 136-01, 136-02 \\
\hline & Nereis (Neanthes) micromma Harper, 1979 & & 3 & MZ-UCR 137-01 \\
\hline & Alitta succinea (Leuckart, 1847) & 74 & 2 & MZ-UCR 138-01, 139-02 \\
\hline & Nereis oligohalina (Rioja, 1946) & 7 & & MZ-UCR 138-03 \\
\hline & Perinereis sp. & 30 & 2 & MZ-UCR 139-01 \\
\hline & Platynereis dumerilii (Audouin \& Milne Edwards, 1834) & 8 & & MZ-UCR 139-06 \\
\hline Onuphidae & Diopatra ornata Moore, 1911 & & 2 & \\
\hline Owenidae & Owenia collaris Hartman, 1955 & & 1 & \\
\hline Phyllodocidae & Phyllodoce sp. & & 1 & \\
\hline Polynoidae & Lepidonotus spiculus (Treadwell, 1906)* & 20 & 2 & MZ-UCR 138-02 \\
\hline \multirow[t]{3}{*}{ Spionidae } & Boccardia proboscidea Hartman, 1940* & 1 & & MZ-UCR 280-02 \\
\hline & Dipolydora socialis (Schmarda, 1861) & 2 & & MZ-UCR 280-01 \\
\hline & Polydora rickettsi Woodwick, $1961 *$ & 1 & & MZ-UCR 139-04 \\
\hline Syllidae & Brania sp. & 4 & & MZ-UCR 139-05 \\
\hline Total & & 429 & 18 & \\
\hline
\end{tabular}

* New report for Costa Rica.

** New report for Pacific of Central America.
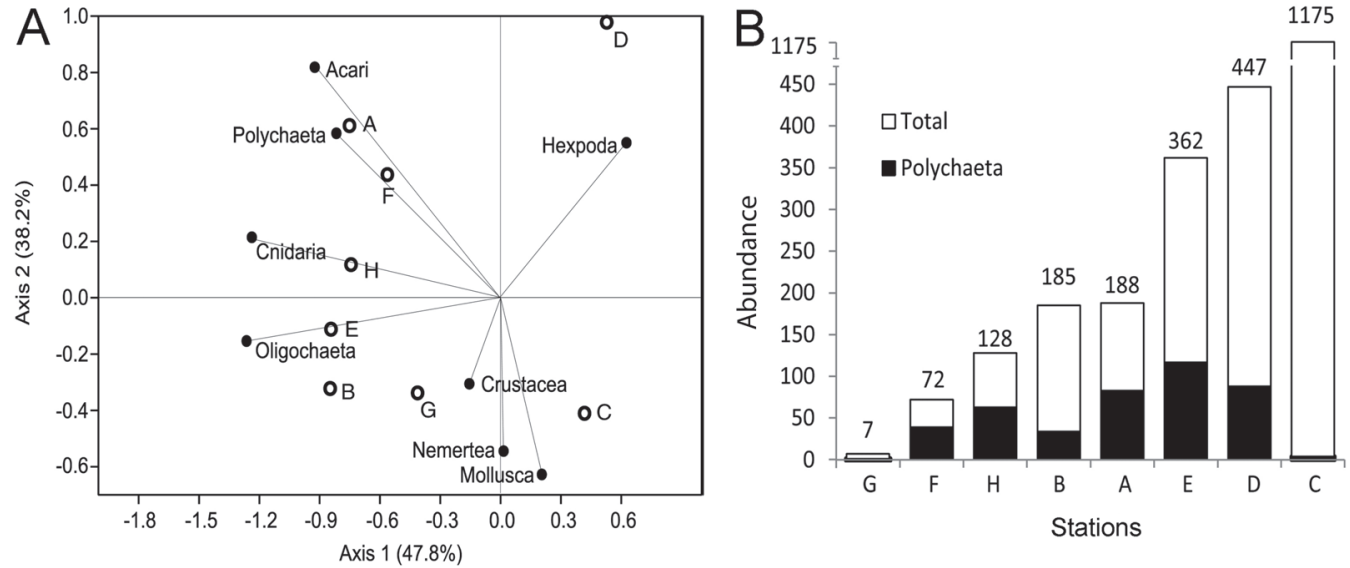

Fig. 3. A) Correspondence analysis showed the ordination of the decaying wood samples (A-H), and the abundance by groups (vectors); B) Contribution of the polychaetes in the total abundance by station. The stations of the decaying wood are sort from low to high total abundance. 


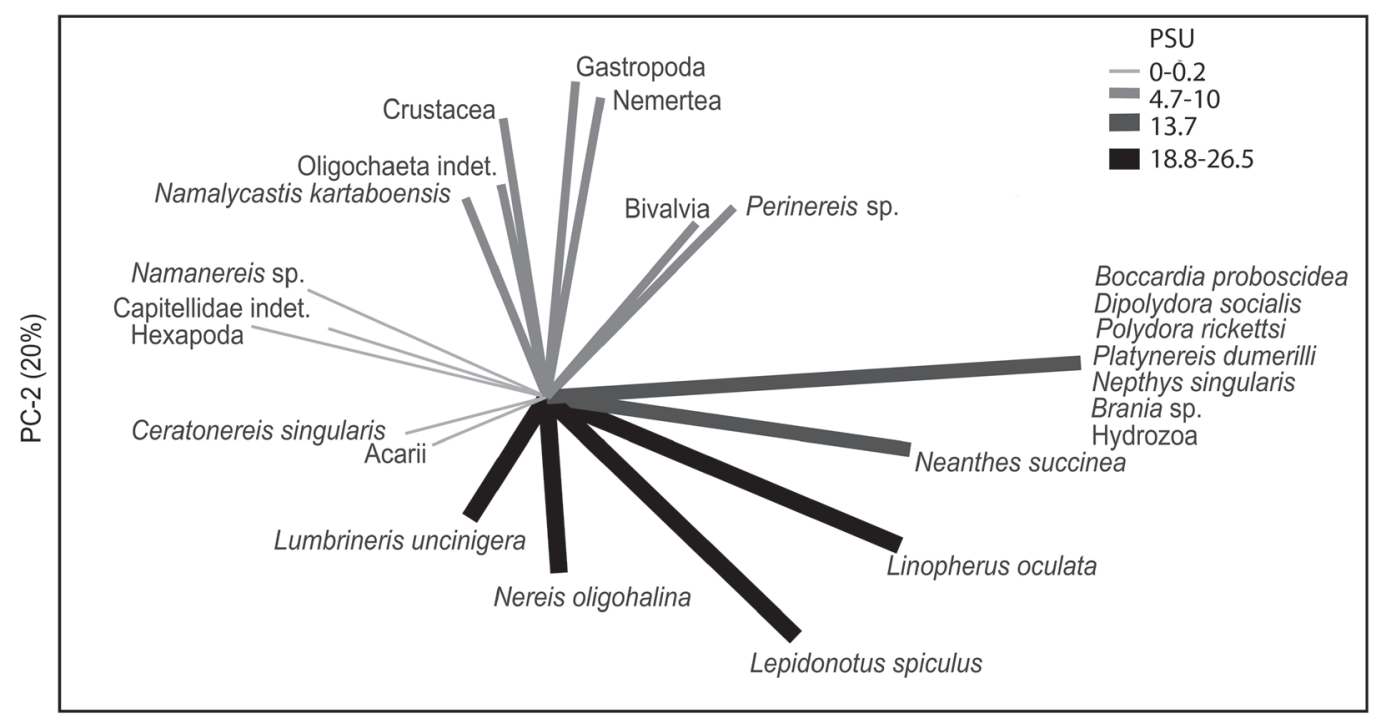

PC-1 (38\%)

Fig. 4. Principal Component Analysis based on the correlation matrix of the taxa abundance, in the salinity gradient. Lines are the vectors of the direction in that the abundance of each taxa increased. The color and width of the vectors indicate the salinity range (PSU) in that the taxa reach a peak in abundance. Térraba mangrove, Costa Rica.

of the gradient contained the highest number of polychaete taxa (15). A. succinea was most abundant between 13 and 18 PSU while the rest of the polychaetes were present in the higher salinity sites (18-26 PSU) (Fig. 4).

\section{Polychaeta-new records}

Family Amphinomidae

Linopherus oculata (Treadwell, 1941)

(Fig. 5A, B)

\section{Synonyms}

Linopherus oculata (Treadwell, 1941); Fauchald \& Reiner, 1975: 82; Fauchald, 1977: 12.

Pseudeurythoe oculata (Treadwell, 1941); Hartman, 1956: 274; Fauchald, 1972: 38-40.

Eurythoe oculata Treadwell, 1941:18, Fig. 1-3. Eurythoe dubia; Monro, 1933:5-6, Fig. 1 [not Horst, 1912]
Material examined: Térraba mangrove, Puntarenas: "Boca Zacate", 8/VIII/2003, MZUCR 139-03; "Playón Daniel, Sector 3", 10/ IX/2002; "El ñeco", 20/III/2003.

Remarks: The specimens have smooth antenna. One sexually mature specimen (with large neurosetae and eggs) have two pairs of large eyespots (Fig. 5A) (which were smaller in immature specimens), the first pair is larger than the second (Fig. 5B). Branchiae are located on the posterior face of the notopodia beginning from the third setiger and are absent in the last two setigers, concordant with descriptions of L. oculata in Treadwell (1941), Hartman (1956), and Fauchald and Reimer (1975). Treadwell (1941) found L. oculata from the Pacific coast of Panama. In another similar species, Linopherus ambigua (Monro, 1933), the smooth antenna and branchiae begin on the third setiger (Yáñez-Rivera, 2009), but the branchiae are limited to the anterior two thirds 

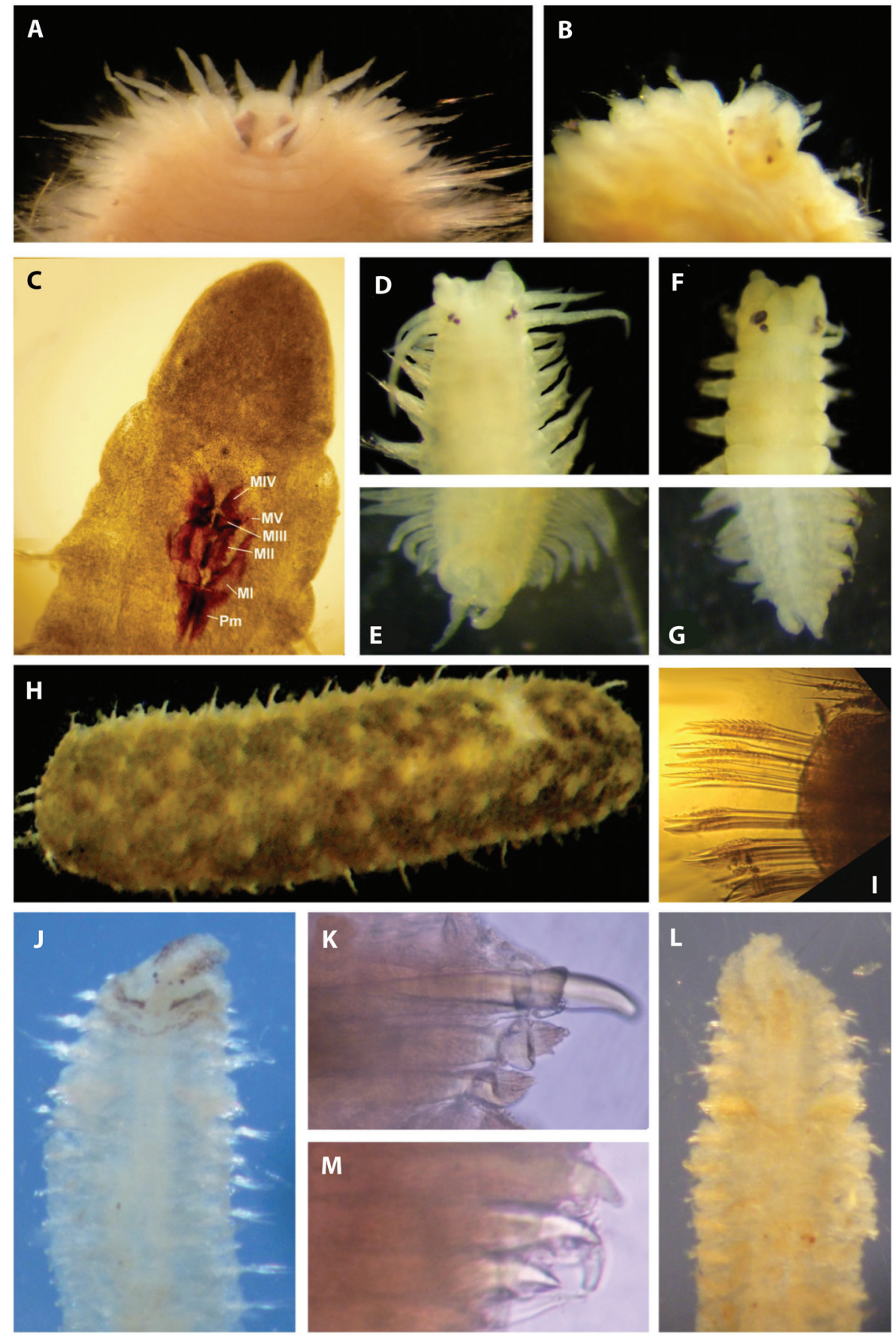

Fig. 5. Polychaeta new records; Linopherus oculata (Treadwell, 1941), A) sexually mature specimen with two pair of large eyes, B) no mature specimens; Socoletoma uncinigera (Hartmann-Schröder, 1959), C) five pairs of maxillas (MI-MV) and Pm: carriers; Namalycastis kartaboensis (Treadwell, 1926), D) anterior end, E) pygidium; Namanereis sp., F) anterior end, G) pygidium; Lepidonotus spiculus (Treadwell, 1906), H) dorsal view, I) thorny unidentate neurosetae; Boccardia proboscidea Hartman, 1940, J) anterior end, K) densely bristle-topped setae of setiger five; Polydora rickettsi Woodwick, 1961, L) anterior end, M) modified setae with lateral teeth of setiger five. Térraba mangrove, Costa Rica. 
of the body (Fauchald \& Reiner, 1975). This is a new record of the species for Costa Rica.

\section{Family Lumbrineridae \\ Scoletoma uncinigera}

(Hartmann-Schröder, 1959)

(Fig. 5C)

\section{Synonyms}

Scoletoma uncinigera (Hartmann-Schröder, 1959); Carrera-Parra, 2009: 273.

Lumbrinereis uncinigera Hartmann-Schröder, 1959: 161-163, Fig. 153-158.

Material examined: Térraba mangrove, Puntarenas, "El ñeco", 20/III/2003, MZ-UCR 135-01.

Remarks: Prostomium entire, the five pairs of maxillae (Fig. 5C) agree with the description of Hartmann-Schröder (1959). The maxillae II is in similar length to maxillae I, as in the Fig. 158 of Hartmann-Schröder (1959), for this species. The first parapodia lacks branchiae. The postsetal lobe is digitiform; the aciculae are yellow, and only multidentate, simple hooded hooks are present. These characteristics indicate that the specimen is S. uncinigera (Hartmann-Schröder, 1959; Carrera-Parra, 2009). This species has been reported from El Salvador by Hartmann-Schröder (1959). This is a new record of the species for Costa Rica.

\section{Family Nereididae}

Namalycastis cf. kartaboensis

(Treadwell, 1926)

(Fig. 5D, E)

\section{Synonyms}

Namalycastis kartaboensis (Treadwell, 1926); Glasby, 1999: 57-59, Fig. 1C, 23A-H, 24; Table 4.

Namalycastis kartaboensis Treadwell, 1926: 101-103, Fig. 33A-C.
Material examined: Térraba mangrove, Puntarenas, 10/X/2002, MZ-UCR 134-01

Remarks: The lack of pharyngeal papillae and paragnaths, and the reduced parapodia indicated this specimen is of Namanereidinae, and the pygidium with multi-incised rim characterized then as genus Namalycastis (Fig. $5 \mathrm{E})$. The specimen is similar to the redescription of N. kartaboensis by Glasby (1999). The body has 128 setigers and is uniform in width anteriorly and tapers gradually in the posterior. The dorsum is convex, and the ventrum is flat. A narrow longitudinal groove is present on the prostomium. The specimens have two pairs of black eyespots with the posterior pair slightly smaller that the anterior (Fig. 5D). Antennae are smooth and extend to the tip of the palpophore. Jaws with a single robust terminal tooth, five subterminal teeth and seven proximally ensheathed teeth. Tentacular cirri with cirrostyles weakly segmented. Dorsal cirri decreasing slightly in length posteriorly. Notopodial sesquigomph spinigers are present from setiger 4-5, supra-neuroacicular setae include sesquigomph spinigers, in postero-acicular fascicles, and heterogomph falcigers, in preacicular fascicles. Supra-neuroacicular falcigers in setiger ten with smooth blades (serrations are absent in blades). This character is only present in Namalycastis brevicornis Glasby, 1999 and $N$. kartaboensis, but the blade 5.0-7.7 $\times$ longer than width of shaft head is characteristic of $N$. kartaboensis as in the specimen found (Glasby, 1999). The Sub-neuroacicular setae include heterogomph spinigers in post-acicular fascicles and heterogomph falcigers in preacicular fascicles, with smooth blades in the mid-posterior region. Sub-neuroacicular spinigers in mid-posterior parapodia with blades having coarse serrations prox imally.

The species N. kartaboensis is been previously reported from Surinam and Guyana (Glasby, 1999), and by this reason, the single 
specimen found is identified as $N$. cf. kartaboensis. This is a new record for the Pacific coast of Central America.

\section{Namanereis sp.}

(Fig. 5F, G)

Material examined: Térraba mangrove, Puntarenas, Costa Rica: "Sector 2, Cuatro bocas", 21/XI/2002, MZ-UCR 136-01, 136-02; "Shrimp station", 10/X/2002; "Tripa de pollo" estuary, 30/I/2003; “El ñeco”, 20/II/2003.

Remarks: The lack of pharyngeal papillae and paragnaths, and reduced parapodia indicated that this specimen is Namanereidinae. The specimens are placed in Namanereis by the presence of acicula, without notosetae in the parapodia. Also, the genus have a tripartite pygidium (Fig. 5G), with two smaller lateral lobes and a smaller, pointed dorsal lobe; and the anus is terminal (Glasby, 1999). Specimens have 28-83 setigers with a mode of 67 . The worms are uniform in width, tapering in the far posterior; convex dorsally and flat ventrally. The prostomium has an anterior cleft or shallow dorsal depression. The antennae are cirriform and smooth and slightly shorter than the palpophore. Two pairs of black eyespots present with the posterior pair smaller. Three pairs of tentacular cirri are present (Fig. 5F). This is the first record of this genus for the Pacific coast of Central America. The individuals presented heterogomph falcigers and spinigers with serration on the shaft. This is a possibly non described species for the region.

\section{Family Polynoidae}

Lepidonotus spiculus (Treadwell, 1906)

(Fig. 5H, I)

\section{Synonyms}

Polynoe spicula Treadwell, 1906: 151-1152, Fig. 11.

Lepidonotus caelorus; Hartman, 1939: 44. (Not Moore, 1903).

Lepidonotus spiculus; Ruff, 1995: Fig. 3.16

A-H.
Lepidonotus spiculus (Treadwell, 1906); Salazar-Silva, 2006: 151.

Material examined: Térraba, Puntarenas, "El ñeco", 20/III/2003, MZ-UCR 13802; "Sector 3, Playón Daniel, tranque 1", 10/IX/2002; "Sector 3, Playón Daniel", 10/ IX/2002; "Boca zacate", 08/VIII/2003; "Playón Estero el Plato", 09/XII/2002.

Remarks: At least 26 segments, twelve pairs of elytra with macro and microtubercles, the former conic and large. The specimens presented a thorny and unidentate neuroseta (Fig. 5H, I) (Salazar-Silva, 2006). This is a new record of the species for Costa Rica.

\section{Family Spionidae}

Boccardia proboscidea Hartman, 1940

(Fig. 5J, K)

Boccardia proboscidea Hartman, 1940: $383-$ 387, Fig. la-j.

Material examined: Térraba, Puntarenas, “Boca Zacate", 8/VIII/2003, MZ-UCR 280-02.

Remarks: Setiger five with two types of modified setae, some with densely bristletopped (Fig. 5K). Prostomium with eyespots (Fig. 5J). Hooded hooks have teeth of different size (Fauchald, 1977; Delgado-Blas, 2009). The species was reported in Panamá by Fauchald (1977). This is a new record of the species for Costa Rica.

\section{Polydora rickettsi Woodwick, 1961}

(Fig. 5L, M)

Polydora rickettsi Woodwick, 1961:78-81, Fig. $1-7$

Material examined: Térraba, Puntarenas, "Boca Zacate", 8/VIII/2003, MZ-UCR 139-04.

Remarks: Without eyespots (Fig. 5L), Hooded hooks from setiger seven. Modified setae of setiger five with lateral accessory 
teeth (Fig. 5M) (Blake, 1996; Delgado-Blas, 2009). This is a new record for this species in Central America.

\section{DISCUSSION}

The mangrove habitats: The logs deposited in mangrove floors represent shelter and food sources for various taxa. Decaying wood, as well as the roots of the mangrove trees, are hard substrates that are colonized by borer species and later by species that use this newly generated living space. These are three dimensional structures that accumulate sediment in their holes and crevices but since the logs are exposed to the water current during the tidal cycle, they remain well oxygenated. In this way, a high abundance of several groups can be found in the decaying wood. On the contrary, the fine grain soft bottom in the mangrove is anoxic below the $2 \mathrm{~cm}$ superficial layer (Vargas, 1987). Infaunal species are reduced in their abundance in anoxic sediment (Alongi, 1990; Little, 2000). These conditions probably explain the higher abundance and diversity of fauna found in decaying wood when compared to sediment samples.

Some taxa, such as the sedentary tube worms Diopatra ornata and Owenia collaris, were only found in the mangrove sediments studied. These species are not able to make their tubes in the decaying wood habitat. Also, Echinodermata and Sipuncula were absent in wood substrates of the Térraba mangrove, possibly due to their incapability to bore in the wood and by the low salinity measured in the sampling sites. Finally, the high percentage of crustaceans in the sediment samples is explained by the fact that the methodology was directed towards the capture of this type of organisms (Echeverría-Sáenz et al., 2003).

Polychaetes: The differences in the species reported from sediments and decaying wood in Térraba mangrove can be related to the ability of organisms to bore in the wood or by salinity preferences. Polychaetes presented lower diversity in the decaying wood than in the sediment samples with the main difference being the dominance of the families Capitellidae and Nereididae in the decaying wood. The family Nereididae has been found in several mangrove roots in previous surveys, in Costa Rica (Dean, 2001a). The species Alittas succinea was abundant in decaying wood and was present in lower abundances, in the sediments. In Punta Morales, Gulf of Nicoya, the same worm (as Neanthes succinea) was found in mangrove roots and the near intertidal rubble bottom. Another nereid, Platynereis dumerilii (Audouin \& Milne Edwards, 1834), was collected only in the decaying wood, but the previous record of this species was found in a rocky intertidal tide pool, in Golfo de Papagayo (Dean, 2001a). Perinereis seridentata (Hartmann-Schröder, 1959) is a species collected on intertidal mud and mangrove roots of Golfo Dulce. The Perineis species found in Térraba mangrove was collected in wood and sediment samples. Nereis oligohalina (Rioja, 1946) was found only in the decaying wood of Térraba. Moreover, N. oligohalina was collected in mangrove roots at Jicaral, Gulf of Nicoya, and sediments of Golfito mangrove (Dean, 2001a). Another nereid species, Nereis (Neanthes) micromma Harper, 1979, was found only in sediments of Térraba mangrove but Dean (2001a) reported this species from mangrove roots in Punta Morales, Gulf of Nicoya. Nereididae specimens of the same species of the present study were reported in similar mangrove habitats of other tropical sites (LondoñoMesa, Polanía, \& Vélez, 2002; Molina-Lara \& Vargas, 1995). The results represent an extension of the knowledge of the natural history of these species in the Costa Rican Pacific coast.

The subfamily Namanereidinae was found in the decaying wood of Térraba mangrove. This subfamily is known to live in the littoral and supralittoral areas, in association with decaying wood and leaves of mangroves systems (Glasby, 1999). One of the species collected in Térraba was Namalycastis cf. kartaboensis, which was previously reported from muds in the Surinam River. Another species of the same genus, Namalycastis borealis Glasby, 
1999, has been reported associated with mangrove roots in Belize. Similar associations with decaying vegetative matter have been noted for Namalycastis abiuma (Grube, 1872) (circumtropical species) and Namalycastis indica (Southern, 1921) from India (Glasby, 1999).

Another species of Namanereidinae, Namanereis sp., was found in the present survey. Worms of the same genus such as Namanereis amboinensis have been associated with dead and rotten vegetation in Belize, and in other places it has been found in decaying vegetation of coastal waters. The association with decaying vegetal matter is also characteristic of the circum-global Namanereis littoralis spp. gp., Namanereis catarractarum (Feuerborn, 1931) in the Indopacific, Namanereis hummelincki (Augener, 1933) in the Caribbean, and Namanereis pontica (Bobretzky, 1872) in the Black sea and Mediterranean (Glasby, 1999).

Namalycastis and Namanereis from Térraba could possibly play a role in the degradation of vegetation. The species Namalycastis borealis was reported feeding in wood by Glasby (1999). Possibly, similar to fresh water Namanereidinae, the mangrove populations use decaying wood and roots as food sources but are also facultative predators of insect larvae and other annelids (Benbow \& Burky, 2001).

Capitellids and oligochaetes are subsurface deposit feeder worms (Fauchald \& Jumars, 1979), and their presence in mangrove zones was previously reported by Dean (2001b). The logs contain a high percentage of organic matter and sediment was accumulated in their holes and crevices. In this way, decaying wood is a perfect habitat to opportunist worms as capitellids and oligochaetes (Rizzo \& Amaral, 2001; Dean, 2001b).

Benthic fauna and salinity gradient: Kaller and Kelso (2006) found that insects and molluscs are the main components in decaying woods, of coastal freshwater streams, in SouthWestern Louisiana. The adaptations of these groups to wood boring may have allowed them to dominate the decaying wood in low salinity regimes. The lower salinity in some stations of the Térraba mangrove showed increases in the presence of freshwater insects in the wood, but they are absent in the sediment. Marine sediment is usually composed of fine sand, silt, and clay and the freshwater fauna of streams, other than some dipterans are not adapted to inhabit the fine sediments of estuaries (Kaller $\&$ Kelso, 2006).

Only some polychaetes (Capitellids and Namanereidinae) were found in logs located at salinities below 5 PSU, but they were highly abundant. In the Urías estuary, Sinaloa, Mexico, the capitellids were most abundant in the sediment of the inner estuary (and bordered by mangrove forest), than in the mouth of the estuary (Méndez, 2002). Also, a high percent of the species of Namanereididae is reported for low salinity habitats (Glasby, 1999; Benbow \& Burky, 2001).

The annelids at a generic level found in the mangrove habitats of the present study (Lepidonotus, Diopatra, Alitta, Perineis and Namalycastis) are the same found by Metcalfe and Glasby (2008) in the tropical regions of Australia. They found a change in the assemblages from seaward (high abundance and species richness) to landward, in the mangrove of Darwin Harbour. Most of the organisms at same generic level showed a reduction to low salinity in Térraba mangrove.

To conclude, the decaying wood and sediments in the mangrove of Térraba, showed dissimilarities in the composition and identity of their fauna. In this way, the biodiversity was increased by the microhabitats inside the mangrove forest. The polychaetes play diverse roles in the food chains in this place, where some species possibly degrade decaying wood and other species are deposit feeders or carnivores. The association with other invertebrates, and estuarine gradient, results in a high dynamic community.

\section{ACKNOWLEDGMENTS}

We gratefully thank the Instituto Costarricense de Electricidad (ICE) that financed the fieldtrips to Térraba mangrove and Rita 
Vargas, who helped with the separation of individuals from decaying wood. Also, the Museo de Zoología provided the space to work with the samples.

\section{RESUMEN}

Poliquetos asociados a madera en descomposición en el manglar de Térraba, Pacífico Sur, Costa Rica: Este artículo presenta datos sobre los taxones de fauna, con énfasis en poliquetos; hallados en madera en descomposición y sedimentos. El estudio se realizó a través de un gradiente de salinidad dentro de un manglar estuarino de Costa Rica. Se capturaron los organismos destruyendo los leños encontrados en el piso del manglar Térraba. También, se sacó muestras de sedimento con un cilindro plástico. Se encontraron siete filos diferentes en las muestras del sedimento. De los 192 individuos encontrados, 18 eran poliquetos, con nueve familias y 11 especies. Al inspeccionar las muestras de madera en descomposición se encontró 2564 individuos, distribuidos en cinco filos. Los poliquetos sumaron 429 individuos en ocho familias y 16 especies. Aunque los poliquetos fueron más abundantes en la madera deteriorada, su diversidad fue mayor en las muestras de sedimento. La abundancia de poliquetos en los leños se asoció negativamente con el número de individuos de Mollusca, Hexapoda y Crustacea. Se encontró que el gradiente de salinidad explica en gran medida el cambio en la composición de fauna. La disimilitud en la composición de fauna bentónica hallada en la madera deteriorada y los sedimentos en el manglar de Térraba, indicó que la biodiversidad aumenta al interior del manglar, gracias a la diversidad de micro hábitats. Finalmente varios géneros o especies de poliquetos son nuevos registros para Costa Rica y en general para la Costa Pacífica Centroamericana.

Palabras clave: manglar Térraba, Namaneridinae, biodiversidad, ecología estuarina, poliquetos.

\section{REFERENCES}

Alongi, D. M. (1990). The ecology of tropical soft-bottom benthic ecosystems. Oceanography and Marine Biology: An Annual Review, 28, 381-496.

Benbow, M. E., \& Burky, A. J. (2001). Hawaiian Freshwater Polychaeta: a Potentially Substantial Trophic Component of Stream Depositional Habitats. Micronesica, 34, 35-46.

Blake, J. A. (1996). Family Spionidae Grube, 1850. In J. A. Blake, B. Hilbig \& P. H. Scott (Eds.), Taxonomic Atlas of the benthic fauna of the Santa Maria Basin and the Western Santa Barbara Channel, No. 6. (pp. 81-223). Santa Barbara, California: Santa Barbara Museum of Natural History.
Carrera-Parra L. F. (2009). Lumbrineridae Schmarda, 1861. In J. A. de León-González, J. R. BastidaZavala, L. F. Carrera-Parra, M. E. García-Garza, A. Peña-Rivera, S. I. Salazar-Vallejo \& V. Solís-Weiss (Eds.), Poliquetos (Annelida, Polychaeta) de México y América Tropical (pp. 263-275). Monterrey: Universidad Autónoma de Nuevo León.

Chicas, F. A. (1995). Distribución, diversidad y dinámica poblacional de la ictiofauna commercial de la Reserva Forestal Térraba-Sierpe, Puntarenas, Costa Rica (Master's thesis). Universidad de Costa Rica, San Pedro, San José.

Cordero, P. (2000). El Manglar más Grande de Costa Rica: Experiencias de la UICN, San José: Unión Internacional para la Conservación de la Naturaleza.

de León-González, J. A., Bastida-Zavala, J. R., CarreraParra, L. F., García-Garza, M. E., Peña-Rivera, A., Salazar-Vallejo, S. I., \& Solís-Weiss, V. (Eds.). (2009). Poliquetos (Annelida, Polychaeta) de México y América Tropical. Monterrey: Universidad Autónoma de Nuevo León.

Dean, H. K. (2001a). Some Nereididae (Annelida: Polychaeta) from the Pacific coast of Costa Rica. Revista de Biología Tropical, 49 (Suppl. 2), 37-67.

Dean, H. K. (2001b). Capitellidae (Annelida: Polychaeta) from the Pacific coast of Costa Rica. Revista de Biología Tropical, 49 (Suppl. 2), 69-84.

Dean, H. K. (2004). Marine biodiversity of Costa Rica: Class Polychaeta (Annelida). Revista de Biología Tropical, 52 (Suppl. 2), 131-181.

Delgado-Blas, V. H. (2009). Spionidae Grube, 1850. In J. A. de León-González, J. R. Bastida-Zavala, L. F. Carrera-Parra, M. E. García-Garza, A. Peña-Rivera, S. I. Salazar-Vallejo \& V. Solís-Weiss (Eds.), Poliquetos (Annelida, Polychaeta) de México y América Tropical (pp. 589-614). Monterrey: Universidad Autónoma de Nuevo León.

Dittel, A. I., Epifanio, C. E., \& Lizano, O. (1991). Flux of crab larvae in a mangrove creek in the Gulf of Nicoya, Costa Rica. Estuarine, Coastal and Shelf Science, 32, 129-140.

Echeverría-Sáenz, S., Vargas, R., \& Wehrtmann, I. S. (2003). Diversity of decapods inhabiting the largest mangrove system of Pacific Costa Rica. Nauplius, 11(2), 91-97.

Fauchald, K. (1972). Benthic polychaetous annelids from deep water off Western Mexico and adjacent areas in the Eastern Pacific Ocean. Allan Hancock Foundation Monographs in Marine Biology, 7, 1-575.

Fauchald, K., \& Reimer, A. A. (1975). Clave de poliquetos panameños con la inclusión de una clave para todas las familias del mundo. Boletín del Instituto Oceanográfico de la Universidad de Oriente, 14, 71-94. 
Fauchald, K. (1977). Polychaetes from intertidal areas in Panama, with a review of previous shallow-water records. Smithsonian Contributions to Zoology, 221, $1-81$.

Fauchald, K., \& Jumars, P. A. (1979). The diet of worms: a study of polychaete feeding guilds. Oceanography and Marine Biology - An Annual Review, 17, 193-284.

Glasby, C. J. (1999). The Namanereidinae (Polychaeta: Nereididae). Part 1, taxonomy and phylogeny. Records of the Australian Museum, Supplement, 25, $1-146$.

Hammer, Ø., Harper, D. A. T., \& Ryan, P. D. (2001). Past: Paleontological Statistics Software Package for Education and Data Analysis. Palaeontologia Electronica, 4, 1-9.

Hartman, O. (1939). Polychaetous annelids, 1. Aphroditidae to Pisionidae. Allan Hancock Pacific Expeditions, 7, 1-155.

Hartman, O. (1940). Boccardia probosidea, a new species of spionid worm from California. Journal of the Washington Academy of Sciences, 30, 382-387.

Hartman, O. (1956). Polychaetous annelids erected by Treadwell, 1891 to 1948 , together with a brief chronology. Bulletin of the American Museum of Natural History, 109, 243-310.

Hartmann-Schröder, G. (1959). Zur Okologie der Polychaeten des mangrove-estero-gebietes von El Salvador. Beiträge zur Neotropischen Fauna, 1, 70-183.

Jiménez, J., \& Soto, R. (1985). Patrones regionales en la estructura y composición florística de los manglares de la costa Pacífica de Costa Rica. Revista de Biología Tropical, 33, 25-37.

Jiménez, J. (1994). Los Manglares del Pacifico de Centroamérica. Heredia, Costa Rica: Editorial Fundación UNA.

Kaller, M. D., \& Kelso, W. E. (2006). Short-term decompositional state does not influence use of wood by macroinvertebrates in subtropical, coastal plain streams. Hydrobiologia, 571, 157-167.

Krebs, C. J. (1999). Ecological Methodology, 2nd ed. Nueva York: Addison-Welsey.

Lacerda, L. D., Conde, J. E., Alarcón, C., Álvarez-León, R., Bacón, P. R., D’Croz, L., (...) \& Vannucci, M. (1993). Mangrove Ecosystems of Latin America and the Caribbean: a Summary. In L. D. Lacerda (Ed.), Conservation and Sustainable Utilization of Mangrove Forests in Latin America and Africa Regions. Part I (pp. 1-41). Okinawa, Japan: ITTO/ISME Project PD 114/90 (F)

Lacerda, L. D., Conde, J. E., Kjerfve, B., Álvarez-León, R., Alarcón, C., \& Polanía, J. (2001). American Mangroves. In L. D. Lacerda (Ed.), Mangrove
Ecosystems: Function and Management (pp. 1-62). Berlin: Springer-Verlag.

Lahmann, E. J. (1999). La Reserva Forestal Térraba-Sierpe, Costa Rica: Un ejemplo de uso adecuado del manglar. In A. Yáñez-Arancibia \& A. L. Lara-Domínguez (Eds.), Ecosistemas de Manglar de América Tropical (pp. 291-298). Silver Spring, Maryland: Instituto de Ecología A.C. México UICN/NORMA Costa Rica, NOAA/NMFS.

Little, C. (2000). The Biology of Soft Shores and Estuaries. Oxford: Oxford University Press.

Londoño-Mesa, M, Polanía, J., \& Vélez, I. (2002). Polychaetes of the mangrove-fouling community at the Colombian Archipelago of San Andrés and Old Providence, Western Caribbean Wetlands Ecology and Management, 10, 227-232.

Macintosh, D. J. (1988). The ecology and physiology of decapods of mangrove swamps. Symposium of the Zoological Society of London, 59, 315-341.

Mainardi, V. (1996). El Manglar de Térraba-Sierpe en Costa Rica. Serie Técnica, Informe Técnico No. 284. Turrialba, Cartago, Costa Rica: Centro Agronómico Tropical de Investigación y Enseñanza (CATIE).

Metcalfe, K. N., \& Glasby, C. J. (2008). Diversity of Polychaeta (Annelida) and other worm taxa in mangrove habitats of Darwin Harbour, Northern Australia. Journal of Sea Research, 59, 70-82.

Méndez, N. (2002). Annelid assemblages in soft bottoms subjected to human impact in the Urías estuary (Sinaloa, Mexico). Oceanologica Acta, 25, 139-147.

Molina-Lara, O., \& Vargas, J. A. (1995). Poliquetos (Annelida: Polychaeta) del estero de Jaltepeque, El Salvador una comparación 1959-1991. Revista de Biología Tropical, 43, 195-205.

Monro, C. C. A. (1933). The Polychaeta Errantia collected by Dr. C. Crossland at Colon in the Panama region and the Galapagos Islands during the expedition of the S.Y. St. George. Proceedings of the Zoological Society of London, 1933, 1-96.

Oshiro, L. M. Y., Silva, R., \& Silva, Z. S. (1998). Composição de fauna de braquiúros (Crustacea, Decapoda) dos manguezais da Bahía Sepetiba- R.J. Nauplius, 6, 31-40.

Perry, D. (1988). Effects of associated fauna on growth and productivity in the red mangrove. Ecology, 69, 1064-1075

Polanía, J. (1993). Mangroves of Costa Rica. In, L. D. Lacerda (Project coordinator), Conservation and Sustainable Utilization of Mangrove Forests in Latin America and Africa Regions (pp. 129-137). Okinawa, Japan: ITTO/ISME Project PD 114/90 (F).

Quinn, G. P., \& Keough, M. J. (2003). Experimental Design and Data Analysis for Biologists. Cambridge: Cambridge University. 
Rizzo, A. E., \& Amaral, A. C. Z. (2001). Environmental variables and intertidal beach annelids of São Sebastião Channel (State of São Paulo, Brazil). Revista de Biología Tropical, 49, 849-857.

Ruff, R. E. (1995). Family Polynoidae Malmgren, 1867. In J. A. Blake, B. Hilbig \& P. H. Scott (Eds.), Taxonomic Atlas of the benthic Fauna of the Santa Maria Basin and Western Santa Barbara Channel. The Annelida Part 2. No. 5. (pp. 105-166). Santa Barbara, California: Santa Bárbara Museum of Natural History.

Salazar-Vallejo, S. I., León-Gonzalez, J. A., \& Salaices-Polanco, H. (1988). Poliquetos (Annelida: Polychaeta) de México. Baja California: Universidad Autónoma de Baja California Sur.

Salazar-Silva, P. (2006). Scaleworms (Polychaeta: Polynoidae) from the Mexican Pacific and some other Eastern Pacific sites. Investigaciones marinas (Valparaíso), 34, 143-161.

Silva, M. (2009). Mangroves. In, I. S. Wehrtmann \& J. Cortés (Eds.), Marine Biodiversity of Costa Rica, Central America (pp. 123-130). Berlin: Springer Science+Business Media.

Skov, M. W., Vannini, M., Shunula, J. P., Hertnoll, R. G., \& Cannicci, S. (2002). Quantifying the density of mangrove crabs: Ocypodidae and Grapsidea. Marine Biology, 141, 725-732.

Treadwell, A. L. (1906). Polychaetous annelids of the Hawaiian Islands collected by the Steammer Albatross in 1902. Bulletin of the United States Fish Commission, 23, 1145-1181.
Treadwell, A. L. (1926). A new polychaetous annelid from Kartabo, British Guiana. Zoologia, 7, 101-104.

Treadwell, A. L. (1941). Eastern Pacific expeditions of the New York Zoological Society. Polychaetous annelids from the west coast of Mexico and Central America. Zoologica, 26, 17-24.

Vargas, J. A. (1987). The benthic community of an intertidal mud flat in the Gulf of Nicoya, Costa Rica. Description of the community. Revista de Biología Tropical, $35,229-316$.

Vega, A. J. (1994). Estructura de Población, Rendimiento y Épocas Reproductivas de Anadara spp. (Bivalvia; Arcidae) en la Reserva Forestal Térraba-Sierpe, Puntarenas, Costa Rica, con Recomendaciones para su Manejo (Master's thesis). Universidad de Costa Rica, San Pedro, San José, Costa Rica.

Wehrtmann, I., \& Dittel, A. I. (1990). Utilization of floating mangrove leaves as a transport mechanism of estuarine organisms, with emphasis on Decapod Crustacea. Marine Ecology Progress Series, 60, 67-73.

Woodwick, K. H. (1961). Polydora rickettsi, a new species of spionid polychaete from Lower California. Pacific Science, 15, 78-81.

Yáñez-Rivera, B. (2009). Amphinomidae Savigny in Lamarck, 1818. In, J. A. de León-González, J. R. Bastida-Zavala, L. F. Carrera-Parra, M. E. García-Garza, A. Peña-Rivera, S. I. Salazar-Vallejo \& V. SolísWeiss (Eds.), Poliquetos (Annelida, Polychaeta) de México y América Tropical (pp. 77-88). Monterrey: Universidad Autónoma de Nuevo León. 